\title{
FAZEKAS FLóRA*
}

\section{Az uniós tagság alkotmányos alapjai az Alaptörvény előtt és után}

\author{
Európai Unió - magyar uniós tagság - Európa-klauzula - alkotmányos \\ felhatalmazás - 22/2012. (V. 11.) AB határozat
}

Az uniós és a magyar jog viszonyát elsődlegesen az alkotmány rendelkezései határozzák meg. Az Alkotmánybíróság e rendelkezések alapján, azokat értelmezve alakíthat ki egységes alkotmányjogi álláspontot e jogrendszerek viszonyát illetően. Az uniós tagságot érintő alkotmányos normák között kulcsfontosságú az uniós csatlakozásra felhatalmazást adó ún. Európa-klauzula. E rendelkezést a csatlakozás időpontjában az akkori Alkotmányba 2002-ben beemelt 2/A § (1) bekezdése tartalmazta. Ma a klauzula látszólag alig módosult szöveggel az Alaptörvény ${ }^{1}$ E) cikk (2) bekezdésében található. Az Európa-klauzula mellett az Alkotmány és az Alaptörvény további, az uniós tagság szempontjából lényeges rendelkezéseket is tartalmaz, például az európai egység megteremtésében való közremüködésre vagy az Országgyűlés és a Kormány uniós ügyekben való együttműködésére vonatkozóan. Ezeknek adott esetben fontos szerepe lehetne az alkotmánybírósági esetjogban, bár erre vonatkozóan egyelöre kevés szándék mutatkozik.

$E$ tanulmány célja, hogy bemutassa és értékelje Magyarország uniós tagságának alkotmányos alapjait. Áttekinti azt az alkotmánymódosítási folyamatot, amelynek eredményeképp megszületett a korábbi Alkotmány integrációs klauzulája, az alkotmánybírósági esetjog és különböző jogtudományi álláspontok alapján magyarázza a klauzula szövegét, majd e normát összeveti a hatályos Alaptörvény Európa-klauzulájával. Végül áttekinti a klauzulát értelmező alkotmánybírósági esetjogot. A munka segítséget nyújthat az Alkotmánybíróság uniós joggal kapcsolatos álláspontjának megismeréséhez és az esetjog lehetséges jövőbeli irányainak meghatározásához, erre azonban jelen tanulmány már nem tér ki. ${ }^{2}$

* Egyetemi adjunktus, Debreceni Egyetem Állam- és Jogtudományi Kar, Alkotmányjogi Tanszék, fazekas. flora@law.unideb.hu. A tanulmány egy készülö, hosszabb terjedelmű munkám része. Köszönöm a szöveg korábbi és újabb változataihoz füzött értékes észrevételeket Sólyom Péternek, Tóth Gábor Attilának, Varju Mártonnak és Várnay Ernőnek. A szövegben szereplő vitatható állitások kizárólag az én megállapításaim.

1 Magyarország Alaptörvénye (2011. április 25.). Felváltotta az 1989-90-ben alapjaiban módosított 1949. évi XX. törvényt a Magyar Köztársaság Alkotmányáról. A továbbiakban az alkotmány szó használatával általában utalok a magyar alapnormára, amelybe az Alkotmányt és az Alaptörvényt is beleértem. Ha kifejezetten a 2012-ig hatályos alapnormáról szólok, nagy kezdőbetűvel használom az Alkotmányt.

2 Ehhez az újabb irodalomból lásd többek között FAzEKAs, Flóra: EU Law and the Hungarian Constitutional Court. In Varju, Márton-Várnay, Ernő (eds.): The Law of the European Union in Hungary: Institutions, Processes and the Law, HVG-ORAC, Budapest, 2014, 32-76; VINCZE Attila: Az Alkotmánybíróság straté- 


\section{Az uniós csatlakozáshoz kapcsolódó alkotmánymódosítás indokai}

A magyar alkotmány a legtöbb európai állam alkotmányával összehasonlítva abban a tekintetben a kisebbséghez tartozik, hogy a rendszerváltás óta sem tartalmaz rendelkezést a nemzeti szuverenitásból fakadó hatáskörök nemzetközi szervezetre történő átruházásának általános engedélyezéséről. A Il. világháborút követően a legtöbb európai állam alkotmányába bekerült olyan rendelkezés, amely alapot teremtett az ENSZ-hez való csatlakozásra, különböző nemzetközi közösségekben való részvételre. Az EGK-t alapító tagállamokban az EGK-ban vállalt tagság is ezen alkotmányi rendelkezéseken alapult, a később csatlakozó tagállamok többsége azonban már kifejezetten az Európai Közösségre utaló alkotmányos felhatalmazás alapján csatlakozott. ${ }^{3}$ A 2004-ben belépő volt szocialista államokban - Magyarországhoz hasonlóan - az uniós csatlakozással került integrációs klauzula az alkotmányba. ${ }^{4}$ Az uniós csatlakozás, illetve a 2010-11-es alkotmányozás lehetőséget teremtett volna arra is, hogy a magyar alkotmányt kibővítsék egy általános, nemzetközi együttmüködéshez szükséges, hatáskör-átruházásra felhatalmazást adó rendelkezéssel, erre azonban nem került sor. ${ }^{5}$ Az Alkotmány és az Alaptörvény is csak az európai integrációs szervezetben való részvételre ad kifejezett alkotmányos felhatalmazást.

Az uniós csatlakozás jogi elökészítése során a szakirodalomban széles körben elfogadott volt az az álláspont, miszerint a csatlakozás csak az Alkotmány módosítása után, az Európai Unió számára a hatáskörök átruházását lehetővé tévő alkotmányos felhatalmazás alapján történhet. ${ }^{6} A z$ uralkodó áláspont alapját az Alkotmánybíróság

giái az uniós és a belső jog viszonyának kezeléséhez. In Fekete Balázs-Horváthy Balázs-Kreisz Brigitta (szerk.): A világ mi magunk vagyunk... Liber Amicorum Imre Vörös, HVG-ORAC, Budapest, 2014, 597-611; Vörös Imre: Csoportkép Laokoónnal. A magyar jog és az alkotmánybíráskodás vívódása az európai joggal, HVG-ORAC, Budapest, 2012.

3 MARTONYI János: Magyarország EU-csatlakozásának közjogi feltételei. In Czuczai Jenő (szerk.): Jogalkotás, jogalkalmazás hazánk EU-csatlakozása küszöbén, KJK-KERSZÖV, Budapest, 2003, 22-23; részletesebben CLAES, Monica: Constitutionalizing Europe at its Source: The 'European Clauses' in the National Constitutions: Evolution and Typology, Yearbook of European Law (2005) 81-125.

4 Részletesen Albi, Anneli: "Europe" Articles in the Constitutions of Central and Eastern European Countries, Common Market Law Review (2005) 399-423.

5 Sőt az 1994-1998 közötti alkotmányozási kísérlet során is megjelent az erről szóló elképzelés. Lásd „A szuverenitás" fejezetben a Magyar Köztársaság Alkotmányáról szóló 1997-es és 1998-as tervezeteket (AEB/1/1997; AEB/17/2/1998): Somogyvári István-Kisfaludy Zoltán (szerk.): Az Országgyülés Alkotmány-előkészítő munkájának dokumentumai 1994-1998. 2. Parlamenti Módszertani Iroda, Budapest, 1998, 998, 1059.

6 Chronowskı Nóra: Az Európai Unió és az alkotmány, Európai Tükör, 2000/4., 86; Berke Barna: Az európai közösségi jogrend strukturális elveiről. In lus Privatum - lus Commune Europae. Liber Amicorum Studia Ferenc Mádl Dedicata, ELTE ÁJK Nemzetközi Magánjogi Tanszék, Budapest, 2001, 51-54; SomogYvÁRI István: Az uniós csatlakozás alkotmánymódosítást igénylő kérdései, Európai Közigazgatási Szemle (A Magyar Jog melléklete), 2001/1., 22-25; WALLACHER Lajos: Az Európai Unióhoz való csatlakozás alkotmányos kérdései. In Verebélyi Imre (szerk.): Európai integrációs válogatott tanulmányok, Magyar Közigazgatási Intézet, Budapest, 2001, 139.; MARTONY: i. m., 24; VASTAGH Pál: Magyar jogalkotás, jogalkalmazás az EU-csatlakozásunk küszöbén. In Czuczai (szerk.): i. m., 34; VöRös Imre: Az EU-csatlakozás alkotmányjogi, jogdogmatikai és jogpolitikai aspektusai. In Czuczai (szerk.): i. m., 59; PACzolAy Péter: Alapjogok és az EU (Fórum), Fundamentum, 2003/2., 64.; KUKORELLI István-PAPP Imre: A magyar Alkotmány EU-konformitása. In Kukorelli István: Tradíció és modernizáció a magyar alkotmányjogban, Századvég, Budapest, 2006, 240. 
30/1998. (VI. 25.) AB határozata ${ }^{7}$ jelentette, amelyben az $A B$ rögzítette: a magyarországi jogalkalmazásban csak a népszuverenitásra visszavezethető, demokratikus legitimáción alapuló jogi normák érvényesíthetők, tehát a közösségi (uniós) normák alkalmazásához kifejezett alkotmányos felhatalmazás kell. ${ }^{8}$

Bár ritkábban, de a fentivel ellentétes álláspontok is megfogalmazódtak. Kecskés László a csatlakozást megelőzően keresztülvitt, „elsietett” alkotmánymódosítás helyett ajánlatosabbnak tartotta volna, ha csak a csatlakozást és a Csatlakozási Szerződés Alkotmánybíróság általi felülvizsgálatát követően került volna sor az alkotmánymódosításra. ${ }^{9}$ Később, már a 2002-es alkotmánymódosítást követően azt az álláspontot képviselte, miszerint a Csatlakozási Szerződés aláírásával a szuverenitás részleges átruházása már megtörtént, így az ezt engedélyező alkotmányi klauzula fölösleges, és csak „a hazai jogászok szakmai komfortérzetét javítja”. ${ }^{10}$ Ez a megközelítés azonban nem nevezhető általánosnak: a közjogász társadalom többsége és a jogalkotó szerint is a csatlakozás alkotmányozási kényszerrel járt. ${ }^{11}$ A 2010-11-es alkotmányozás során sem fogalmazódott meg olyan álláspont, mely szerint az Európa-klauzula elhagyása kívánatos volna az új alkotmányból.

Az Alkotmányt az Európai Unióhoz történő csatlakozás alkotmányos feltételeinek megteremtése érdekében a 2002. évi XLI. törvény módosította. ${ }^{12} \mathrm{~A}$ törvény indoklása szerint az Alkotmány ilyen jellegü kiegészítésére leginkább azért volt szükség, mert az Alkotmánybíróság 1998-as határozata értelmében az Alkotmány enélkül nem ad lehetőséget arra, hogy a Magyar Köztársaság a főhatalomból eredő joghatóságának kizárólagosságáról lemondjon, az uniós csatlakozással pedig épp a kizárólagos jogalkotó joghatóság korlátozására kerül sor. A közösségi jog alkalmazásához az Alkotmánybíróság által megkívánt „többletlegitimációt” az alkotmánymódosítás két irányban is kifejezésre juttatta: egyrészt az uniós csatlakozást érintő ügydöntő népszavazásról szóló rendelkezéssel, másrészt az uniós tagsággal összefüggő nemzetközi szerződés megerősítésének és kihirdetésének az alkotmányozó többség akaratához kötésével. ${ }^{13}$

7 ABH 1998, 220. A döntés részletes ismertetését lásd FAZEKAs Flóra: A magyar Alkotmánybíróság viszonya a közösségi jog elsőbbségéhez egyes tagállami alkotmánybírósági felfogások tükrében, PhD-értekezés, Debreceni Egyetem, 2009, 214-237.

8 Egyes szerzők szerint magából a határozatból nem következik, hogy az EU-csatlakozáshoz szükség volt egy alkotmányos csatlakozási klauzulára. A határozat ugyanis csak azokat a körülményeket vette figyelembe, amikor Magyarország nem volt tagja az EU-nak, és nem foglalt állást arról, hogy hazánk EU-tagsága esetén fennállna-e a demokratikus legitimáció vagy sem. CsuHÁnY Péter-Sonnevend Pál: 2/A § [Európai Unió]. In Jakab András (szerk.): Az Alkotmány kommentárja, Századvég, Budapest, 2009, 241; PACzOLAY Péter: Az Európai Unió és az Alkotmánybíróság. In Pesti Sándor-Szabó Máté (szerk.): „Jöjj el szabadság!” Bihari Mihály egyetemi tanár 60. születésnapjára készült ünneplő kötet, Rejtjel, Budapest, 2003, 674.

9 KECSKÉs László: A csatlakozási tárgyalás által meghatározott magyar jogharmonizáció teljesítményéről. In Kurtán Sándor-Sándor Péter-Vass László (szerk.): Magyarország politikai évkönyve 2001-röl l., Demokrácia Kutatások Magyar Központja, 2002, 559.

10 Interjú Kecskés Lászlóval, Magyar Hírlap, 2002. november 8.

11 Számos álláspontot ismertet KECSKÉs László: EU-jog és jogharmonizáció, HVG-ORAC, Budapest, 2011, 952-962.

12 A törvényt az Országgyűlés az uniós csatlakozási tárgyalások lezárását követően négy nappal, 2002. december 17-én fogadta el 361 igen és 4 nem szavazattal, tartózkodás nélkül.

13 BALOGH Zsolt-Holló András-KuKorellı István-SÁRI János: Az Alkotmány magyarázata, KJK-KERSZÖV, Budapest, 2003, 127. 


\section{Az eredeti Európa-klauzula tartalmára vonatkozó javaslatok}

Az alkotmánymódosítás előkészítése során számos elképzelés látott napvilágot azzal kapcsolatban, hogy a csatlakozási klauzulának mit kellene tartalmaznia. Az előkészítés során a hivatalos álláspont is többször változott, emellett a jogirodalom neves képviselői is hangot adtak véleményüknek a klauzula tartalmát illetően. ${ }^{14}$ A klauzula végleges szövege a közjogász szakmán belül inkább csalódást keltett, ugyanis a kormányzati tervezetekhez és szakmai javaslatokhoz képest a végleges módosítás igen szükszavú lett, és a szöveg megfogalmazása sem bizonyult kellően precíznek. ${ }^{15}$

Az első, széles körű szakmai véleményezésre bocsátott 2002-es igazságügy-minisztériumi tervezet ${ }^{16}$ azt javasolta, hogy a csatlakozási klauzula rendelkezzen az EK/EU javára nemzetközi szerződésben történő „szuverenitás-korlátozásról”, amely az Alkotmányból eredő hatáskörök gyakorlásának átengedését jelenti és feltétele a kölcsönösség. A tervezet meghatározott olyan célokat és elveket, amelyeket alkotmányos fenntartásként a cikkbe bele lehetett volna venni, például a jogállamiság, demokrácia, alapjogok védelme, szociális állam, kisebbségvédelem elveit. Vázolt továbbá egy olyan elképzelést is, hogy az Alkotmányba be lehetne emelni a közösségi jog elsöbbségének és közvetlen hatályának érvényesülését garantáló rendelkezést is, $\mathrm{s}$ ehhez kapcsolódóan korlátozni az Alkotmánybíróság közösségi jogot érintő hatáskörét. ${ }^{17}$

A Kormány 2002 októberében nyújtotta be a Parlamenthez az alkotmánymódosításra irányuló törvényjavaslat első változatát. ${ }^{18} \mathrm{~A}$ javaslat az Európa-klauzulát már ekkor új 2/A §-ként kívánta volna beilleszteni. A felhatalmazás eszerint, nevesítve az Európai Uniót, lehetővé tette volna egyes, Alkotmányból eredő hatáskörök gyakorlásának átengedését, illetve azok más tagállamokkal való közös gyakorlását az országgyűlési képviselők kétharmadának szavazatával megerősített és kihirdetett nemzetközi szerződés alapján. A klauzulában szerepelt a közösségi jog és „az Európai Unió egyéb vívmányai" érvényesítésére vonatkozó szabály is. Ez a szövegválto-

14 A csatlakozási klauzula és általában az alkotmánymódosító törvény előkészítéséről, „metamorfózisáról” és elfogadásáról lásd BALOGH et al.: i. m., 127-129; CHRONowskı Nóra: „Integrálódó” alkotmányjog, Dialóg Campus, Budapest-Pécs, 2005, 171-197; CsuHÁNY-SonnEVEnd: i. m., 239-244; KeCsKÉs: EU-jog és jogharmonizáció..., i. m., 952-970.

15 Kritikáját lásd többek között VöRÖs: Az EU-csatlakozás alkotmányjogi, jogdogmatikai és jogpolitikai aspektusai...; CHRONOWSKı Nóra-PETRÉTEI József: EU-csatlakozás és alkotmánymódosítás: minimális konszenzus helyett politikai kompromisszum, Magyar Jog, 2003/8., 449-466.

16 Tézisek az Európai Uniós csatlakozásunkkal összefüggésben az Alkotmány és a jogalkotási törvény módosításáról, IM/EUR/2002/TERVEZET/287/12. sz. munkaanyag (2002. július). Interneten nem hozzáférhető, lásd hozzá ChronowsKI-PETRÉTEl: i. m., 450-452.

17 Paczolay Péter: A magyar alkotmány jövője és az uniós csatlakozás, Politikatudományi Szemle, 2004/1-2., 38. Az AB hatáskörére vonatkozó szabályozás rendezését ugyanígy szükségesnek tartja CHRONOWSKI, NóraDrinóczı, Tímea: A Triangular Relationship between Public International Law, EC Law and National Law? The Case of Hungary. In Wouters, Jan-Nollkaemper, André-de Wet, Erika (eds.): The Europeanisation of International Law. The Status of International Law in the EU and its Member States, TMC Asser Press, The Hague, 2008, 171-172.

18 T/1114. számú törvényjavaslat, 2002. október 15. 
zat tehát az Alkotmányon alapuló hatáskörök gyakorlásának átengedését tette volna lehetővé, azonban az állami szuverenitás védelmére irányuló garanciális szabályokat nem tartalmazott, és a csatlakozást követö újabb hatáskör-átruházásra vonatkozóan nem tette kötelezővé a kétharmados parlamenti többség általi elfogadást. ${ }^{19}$

Ezt a javaslatot a Kormány rövidesen visszavonta, és 2002 novemberében új törvényjavaslatot nyújtott be ${ }^{20}$ amely az elöbbivel ellentétben parlamenti vitára is került. A második törvényjavaslat nagy újdonsága volt, hogy két felhatalmazó klauzulát fogalmazott meg: az első (2/A §) általános jelleggel, bármely nemzetközi szervezet részére lehetővé tette volna az Alkotmányból eredő egyes hatáskörök átengedését, a jogalkotó hatáskör kivételével;21 a második (2/B §) tette volna lehetővé speciális szabályként az alkotmányos hatáskörök Európai Unió részére történő átengedését, illetve többi tagállammal közös gyakorlását.. ${ }^{22}$ A törvényjavaslat mindkét esetben az összes parlamenti képviselő kétharmadának támogatását követelte meg a nemzetközi szerződés megerősítéséhez. Az uniós részvétel korlátaira vonatkozóan garanciális szabályokat (az alapszerződésekben foglaltakhoz kapcsolódó „szükséges mérték" kitételén túl) nem tartalmazott. ${ }^{23} A 7$. $§(2)$ bekezdése helyébe (az abban foglalt rendelkezés jelölését 7/A §-ra változtatva, a nemzetközi jog és a belső jog összhangjának biztosítását előíró rendelkezést követően) az alábbi rendelkezést léptette volna: „A Magyar Köztársaságban a közösségi jog és az Európai Unió egyéb vívmányai az Európai Unió alapító szerződéseinek és az azokból fakadó jogelveknek megfelelően érvényesülnek". Ezzel alkotmányi szintű utalás történt volna a közösségi jog elsőbbségére és közvetlen alkalmazhatóságára, ${ }^{24}$ amibe ugyanakkor beleérthető lehetett volna a tagállami alkotmánybíróságok által az elsőbbség érvényesülésével szemben állított korlátok elismerése is. A rendelkezés elfogadását épp az elsőbbséghez való viszony miatt az ellenzék nem támogatta, így nem lett a végleges szöveg része.

19 Chronowski-Petrétel: i. m., 453-454.

20 T/1270. számú törvényjavaslat, 2002. november 5.

21 A javasolt szöveg: „A Magyar Köztársaság valamely nemzetközi szervezetben való részvétele érdekében nemzetközi szerződés alapján - az abban meghatározott körben - a jogalkotó hatáskör kivételével egyes, Alkotmányból eredő hatásköreinek gyakorlását a nemzetközi szervezet részére átengedheti, vagy e hatásköröket a nemzetközi szervezet többi tagjával közösen gyakorolhatja".

22 A javasolt szöveg: „A Magyar Köztársaság az Európai Unióban tagállamként való részvétele érdekében nemzetközi szerződés alapján - az Európai Uniót, illetőleg az Európai Közösségeket (a továbbiakban: Európai Unió) alapító szerződésekből fakadó jogok gyakorlásához és kötelezettségek teljesítéséhez szükséges mértékig - az Európai Unió részére egyes, Alkotmányból eredő hatásköreinek gyakorlását átengedheti, vagy e hatásköröket a többi tagállammal közösen gyakorolhatja”.

23 Chronowski-Petrétel: i. m., 455.

24 Ezt megerősíti a törvényjavaslat részletes indokolása is. Egyes vélekedések szerint a rendelkezés a közösségi jog alkotmánnyal szembeni alkalmazási elsőbbségének kifejezett elismerését jelentette volna; mások szerint viszont nem szüntette volna meg az alkotmány elsőbbségét. Az előbbihez lásd CsUHÁNY-SONNEVEND: i. m., 243; az utóbbihoz Chronowski-Petrétel: i. m., 456. 
Az elsőbbség elvének alkotmányos szintủ elismerése szinte példa nélküli lett volna a tagállamok között, ${ }^{25}$ és kérdéses, hogy megfelelöen indokolható lett volna-e. ${ }^{26}$ Belső alkotmányjogi szempontból az integrációs klauzula elegendő eszköz ahhoz, hogy az Európai Unió által alkotott jog magyar jogrendszerbe való beáramlását biztosítsa, amely együtt jár az Európai Bíróság által körülhatárolt alapelvek (elsöbbség, közvetlen hatály, összhangban értelmezés) szerinti belső jogi érvényesüléssel. Az elsőbbséget elismerő kifejezett alkotmányos rendelkezés hiánya az Alkotmánybíróság számára lehetőséget teremt arra, hogy a testület fokozatosan, más tagállamok alkotmánybíróságainak sokéves gyakorlatához hasonlóan maga határolja körül az uniós jog elsőbbségének érvényesülési körét, mind az alkotmány, mind az alkotmány alatti rendelkezések tekintetében.

Az alkotmánymódosító törvény 2002 decemberi elfogadásáig a felhatalmazó klauzulákra vonatkozó javaslatok (is) jelentősen módosultak a parlamenti vita során. Az általános felhatalmazó cikkelyt az utolsó pillanatban kiiktatták, és a végül elfogadott Európa-klauzula szövege sem egyezett meg a törvényjavaslatban szereplővel. Bekerült viszont egy teljesen új rendelkezés (6. § (4) bek.) az európai egység megteremtésében való közremüködésre vonatkozó államcélról. Sólyom László szerint a rendszerváltás után az 1989-es Alkotmány egyetlen valóban lényeges, annak identitását érintő módosítása az Európa-klauzula beiktatásával következett be. ${ }^{27}$

\section{Az Európa-klauzula az Alkotmányban}

Az Alkotmányba végül ténylegesen bekerült, az uniós csatlakozáshoz szükséges hatáskörátadásra felhatalmazást adó klauzula, a 2/A § így szólt:

(1) A Magyar Köztársaság az Európai Unióban tagállamként való részvétele érdekében nemzetközi szerződés alapján - az Európai Uniót, illetőleg az Európai Közösségeket (a továbbiakban: Európai Unió) alapító szerződésekböl fakadó jogok gyakorlásához és kötelezettségek teljesitéséhez szükséges mértékig - egyes, Alkotmányból eredö hatásköreit a többi tagállammal közösen gyakorolhatja; e hatáskörgyakorlás megvalósulhat önállóan, az Európai Unió intézményei útján is.

(2) Az (1) bekezdés szerinti nemzetközi szerződés megerösitéséhez és kihirdetéséhez az országgyülési képviselők kétharmadának szavazata szükséges.

${ }^{25}$ A ritka kivételek közé tartozik az Egyesült Királyság, amely az Európai Közösségekröl szóló Törvényben biztosítja, illetve Írország, Szlovákia és Románia, amelyek alkotmánya rögzíti az elsőbbség elvét.

26 Szintén szükségtelennek látja az elsöbbség alkotmányos elismerését JAKAB András: A magyar jogrendszer szerkezete, Dialóg Campus, Budapest-Pécs, 2007, 248; KECSKÉs: EU-jog és jogharmonizáció..., i. m., 959; PACZolaY: i. m., 64. Az elsőbbség alkotmányi szintű rögzítése mellett érvel KuKorelLI István-PAPP Imre: A magyar Alkotmány EU-konformitása, Európai Jog, 2002/6., 4.

27 Sólyom László: A jogállami forradalomtól az EU-csatlakozásig. Az alkotmányfejlődés keretei. In Majtényi László-Miklósi Zoltán (szerk.): És mi lesz az alkotmánnyal?, Eötvös Károly Intézet, Budapest, 2004, 9. Létezik olyan alkotmányjogi álláspont, mely szerint az uniós csatlakozás megfelelő indokot szolgáltatott volna az 1989-ben elmaradt új alkotmány megalkotásához: CHRONowskI: i. m., 167. 
Az Európa-klauzula szövege szerint tehát nemcsak az uniós csatlakozáskor bekövetkező egyszeri szuverenitásátruházás jogalapját teremtette meg, hanem ezután is folyamatosan biztosította a jogalapot az uniós jog magyarországi érvényesülésére. ${ }^{28}$ A végleges szöveg korábbi javaslatokkal való összevetéséből kitünik, hogy a hatáskörök átengedésére („feladására”) való utalás „közös hatáskörgyakorlásra” módosult, tehát a cikk nem mondta ki, hogy az uniós csatlakozással valójában egyes állami hatáskörök átruházásáról, átadásáról van szó. A cikk elsődlegesként a tagállamokkal való közös hatáskörgyakorlást tüntette fel az intézmények útján történő hatáskörgyakorlással szemben, holott a tényleges gyakorlat és az integráció fejlődési iránya ennek a fordítottját mutatja. ${ }^{29} \mathrm{~A}$ szöveg ilyen irányú változtatásai arra utalnak, hogy a jogalkotó minél inkább el akarta kerülni azt a látszatot, hogy az uniós csatlakozással esetleg sérülhet Magyarország nemzeti szuverenitása. ${ }^{30}$

Az alkotmánymódosító törvény általános indokolása szerint „az Európai Unió alapító szerződései a Magyar Köztársaság területén végső soron az Alkotmány felhatalmazása alapján lesznek kötelezőek, mivel az alaptörvény teremti meg annak lehetőségét, hogy a csatlakozási szerződés - nemzetközi szerződésként - a Magyar Köztársaság területén érvényesüljön”. Elvi szinten tehát a hatáskör-átruházásra felhatalmazást adó alkotmányos rendelkezés nyitotta meg a magyar jogrendszert az uniós jog előtt: az Európai Unió által alkotott jog nem pusztán azért érvényesülhet Magyarországon, mert Magyarország az Unió tagja, hanem mert az alkotmány ezt a csatlakozási szerződésen keresztül lehetővé teszi. Az indokolás szerint az állami főhatalom korlátozására önként került sor, ami nem változtatott azon, hogy „a Magyar Köztársaság területén a hatályos jog alapnormája a Magyar Köztársaság Alkotmánya marad”. Az állami főhatalom korlátozása miatt az erről szóló nemzetközi szerződés megerősítéséhez és jövőbeni módosításaihoz alkotmányozó többség szükséges.

A törvény részletes indokolása szerint a 2/A § alkotmányi szinten ad felhatalmazást a jogalkotó joghatóság korlátozásával járó nemzetközi szerződés kötésére, azonban kizárólag az Európai Unió tagjaként és az Európai Unió javára. Az alkotmányos szintű felhatalmazást az állami főhatalom korlátozásának mélysége indokolja. A jogalkotó indokolása szerint a 2/A § alapján megerősített csatlakozási szerződésből Magyarországra nézve a jogalkotó joghatóságát érintő speciális nemzetközi kötelezettség keletkezik az uniós alapszerződések és különösen az alapszerződésben foglalt ún. „hüségklauzula” (korábban az EK-Szerződés 10. cikke, jelenleg az Európai Unióról szóló Szerződés 4. cikk (3) bekezdése ${ }^{31}$ ) alkalmazására. A csatlakozási

28 CSUHÁNY-SONNEVEnd: i. m., 253.

29 Chronowski: i. m., 191.

30 Csuhány-Sonnevend: i. m., 244; SAJó András: Az EU-csatlakozás alkotmányosságra gyakorolt hatása az új tagállamokban, Fundamentum, 2003/2., 16.

31 „Az Unió és a tagállamok a lojális együttmüködés elvének megfelelően kölcsönösen tiszteletben tartják és segítik egymást a Szerződésekből eredő feladatok végrehajtásában.

A tagállamok a Szerződésekből, illetve az Unió intézményeinek intézkedéseiből eredő kötelezettségek teljesítésének biztosítása érdekében megteszik a megfelelő általános vagy különös intézkedéseket.

A tagállamok segítik az Uniót feladatainak teljesítésében, és tartózkodnak minden olyan intézkedéstől, amely veszélyeztetheti az Unió célkitűzéseinek megvalósítását". 
klauzulára épp azért van szükség, mert a csatlakozási szerződés és a hüségklauzula alapján Magyarországnak uniós tagként olyan szabályokat is alkalmaznia kell, amelyeket a csatlakozáskor nem látott elöre, és az Alkotmánybíróság álláspontja szerint ilyen nemzetközi kötelezettségvállaláshoz az Alkotmány kifejezett felhatalmazása szükséges. Az indokolás szerint e szabályok alkalmazása magában foglalja az elsőbbség és a közvetlen hatály elveinek alkalmazását is.

Az Európa-klauzula a törvényi indokolás értelmében két korlátot fogalmaz meg az uniós tagállamokkal történő közös hatáskörgyakorlás tekintetében: 1. a hatáskörök közös gyakorlására csak az uniós alapszerződésekből fakadó jogok gyakorlásához és kötelezettségek teljesítéséhez szükséges mértékig kerülhet sor; 2 . a felhatalmazás csak egyes, Alkotmányból eredő hatáskörök közös gyakorlására szól. Észrevehetjük, hogy a szöveg értelmében emellett korlátot jelent az is, hogy a hatáskörátengedésre csak nemzetközi szerződés alapján kerülhet sor, és csak az EU-ban való tagállami részvétel érdekében ${ }^{32} \mathrm{~A}$ cikk végleges szövege a korábbi szövegváltozatokkal ellentétben nem tartalmazza azt a korlátot, hogy a felhatalmazás nem terjedhet ki az Alkotmány vagy annak egyes alapvetői elvei megváltoztatására. ${ }^{33}$

A cikk értelmében tehát nem adható át több jogalkotói hatáskör az Uniónak, mint amennyit az alapszerződésekben foglalt célok elérése szükségessé tesz; az Unió ultra vires aktusának érvényesítésére nem ad felhatalmazást az Alkotmány. Továbbá, kizárólag az Alkotmány alapján a jogalkotót megillető hatáskörök adhatóak át, és nem kerülhet sor valamennyi jogalkotói hatáskör átadására, hiszen az a nemzeti szuverenitás feladásával, a magyar államiság megszűnésével lenne egyenlő. Mindebböl adódik a kérdés, hogy ki ellenőrzi az alkotmányos felhatalmazásban foglalt korlátok betartását. Belső alkotmányjogi perspektívából a válasz egyértelműen a magyar Alkotmánybíróság. Uniós jogi perspektívából azonban nem feltétlenül: a tagállamok és az Európai Unió között a kezdetektöl fennálló Kompetenz-Kompetenz vita pontosan e kérdés körül forog. ${ }^{34} \mathrm{Az}$ Uniónak átadott hatáskörök terjedelmének meghatározását az Európai Bíróság és a nemzeti alkotmánybíróságok is kizárólagos hatáskörüknek tekintik. A belső alkotmányjogi perspektívát elfogadva a klauzula alapján a magyar Alkotmánybíróságnak is lehetősége nyílhatott arra, hogy megállapítsa: hatáskörrel rendelkezik a 2/A § alapján az Uniónak átadott egyes hatáskörök terjedelmének vizsgálatára. $A z A B$ e hatáskört meg is állapította saját maga számára a Lisszaboni Szerződés alkotmányosságát érintő határozatban. ${ }^{35}$

Az Európa-klauzula végleges szövegét számos bírálat érte a tudomány képviselöi részéről. Felvetődött például, hogy indokoltabb lett volna a cikket az állami szuverenitást kifejező 5. és 6 . § után, új 6/A §-ként beemelni, mivel az nem a 2. §-ban rögzített népszuverenitás korlátozására vonatkozik, hanem az állami szuverenitás

32 A korlátokra vonatkozó rendelkezések részletes dogmatikai értelmezését lásd CsUHÁNY-SoNNEVEND: i. m., 253-265.

33 Ennek szükségessége mellett érvel CHRONOwSKI Nóra-PETRÉTEI József: Elökészületben az Európai Unióhoz való csatlakozással összefüggő alkotmánymódosítás, JURA, 2002/2., 117-118.

34 A probléma áttekintéséhez kiindulópontként lásd Kuмm, Mattias: Who is the Final Arbiter of Constitutionality in Europe? Three Conceptions of the Relationship Between the German Federal Constitutional Court and the European Court of Justice, Common Market Law Review (1999) 351-386.

35 143/2010. (VII. 14.) AB határozat, ABH 2010, 698, IV.2.2. pont. 
körébe tartozó egyes föhatalmi jogosítványok átengedésére; illetve hogy szükséges lett volna a cikkben utalni olyan alkotmányos elvekre, amelyekre a hatáskör-átruházás nem terjedhet ki. ${ }^{36}$ Kritikaként merült fel továbbá, hogy a végleges szöveg nem az állami felségjogok gyakorlásának átruházásáról szól, ${ }^{37}$ valamint hogy nem rendezi a magyar jog és a közösségi jog között fennálló viszonyt ${ }^{38}$ és a közösségi jog jogforrási rendszerbeli helyét. ${ }^{39}$

A 2/A § beiktatásán túl a 2002-es alkotmánymódosító törvény további alkotmányos rendelkezéseket is érintett az uniós csatlakozásra tekintettel. Az Európai Parlament magyar tagjainak választása miatt kibövült a köztársasági elnök hatásköre az EP-választások időpontjának kitüzésével, a választási alapelvekröl szóló rendelkezést az EP-választásokra is kiterjesztették, és az uniós polgárokkal bővült a választójogosultak köre a helyhatósági és az EP-képviselői választásokon. Az Országgyülés és a Kormány hatásköreire vonatkozóan új rendelkezés született egyrészt arról, hogy a Kormány képviseli Magyarországot a kormányzati részvétellel müködő uniós intézményekben, és a napirenden szereplő döntéshozatali javaslatokról tájékoztatja az Országgyűlést; másrészt arról, hogy az európai ügyek koordinációjáról külön törvényt kell alkotni. A monetáris unióhoz való csatlakozás megkönnyítése érdekében az alkotmánymódosítás rögzítette, hogy a Magyar Nemzeti Bank külön törvény alapján felelös a monetáris politikáért. Mindezek mellett az Alkotmányba bekerült egy paragrafus, amely a Csatlakozási Szerződést kihirdető törvény hatálybalépésének napjáig volt csak hatályban, és amely az uniós csatlakozásról szóló, 2003. április 12-én tartandó ügydöntő népszavazásról rendelkezett. ${ }^{40}$

Az alkotmánymódosító törvény mindezeken túl beiktatott egy új (4) bekezdést az Alkotmány 6. §-ába. Eszerint: „A Magyar Köztársaság az európai népek szabadságának, jólétének és biztonságának kiteljesedése érdekében közremüködik az európai egység megteremtésében". Ez az alkotmányi szakasz új államcélt határozott meg, amely az állami szervek felé alkotmányos kötelezettséget teremtett tevékenységük során az integráció céljainak előmozdítására, e célok akadályozásától való tartózkodásra. ${ }^{41} \mathrm{~A}$ rendelkezéssel párhuzamba állítható a német Alaptörvény 23. cikke, amely a Maastrichti Szerződést megelőző alkotmánymódosítás nyomán került a német Alaptörvénybe, és amely az egyesült Európa megvalósításához való

36 ChRONOWSKI-PETRÉTEI: i. m., 458-459; KECSKÉs: A csatlakozási tárgyalás által meghatározott magyar jogharmonizáció..., i. m., 559.

37 Vörös Imre: Az alkotmány módosításának állása és az EU-csatlakozás. In Inotai András (szerk.): EUTanulmányok I., Nemzeti Fejlesztési Hivatal, Budapest, 2004, 1234.

38 SAJó: i. m., 1234.

39 Blutman László: A magyar Lisszabon-határozat: befejezetlen szimfónia luxemburgi hangnemben, Alkotmánybírósági Szemle, 2010/2., 91.

40 Ennek a rendelkezésnek, amely az alkotmánymódosító törvény hatálybalépésével egyidejüleg lépett hatályba, az Alkotmánybíróság előtt megkérdőjeleződött az alkotmányossága, egyrészt arra hivatkozva, hogy mivel a népszavazás időpontjáig nem készül el az uniós joganyag hiteles fordítása, a választópolgárok nem hozhatnak megalapozott döntést; másrészt arra hivatkozva, hogy az a rendelkezés, amely a népszavazásról szóló szakasz csatlakozás napján történő hatályon kívül helyezéséről rendelkezik, figyelmen kívül hagyja a választópolgárok esetleges elutasító döntését. Az $A B$ a 14/2003. (IV. 9.) AB végzésben visszautasította az indítványokat, mivel az Alkotmány hatályos rendelkezéseinek felülvizsgálatára nincs hatásköre.

41 Chronowski-Petrétel: i. m., 460. 
hozzájárulást tüzi célul a Német Szövetségi Köztársaság számára. A német alaptörvényi cikk azonban nem elégszik meg ennek a célnak a meghatározásával, hanem azt is rögzíti, hogy e célkitüzés csak annyiban áll fenn, amennyiben az alapvető alkotmányos értékek (demokrácia, jogállamiság, alapjogok védelme) érvényesülése garantált. ${ }^{42} \mathrm{~A}$ magyar alkotmányi rendelkezés nem utal az európai integrációval szembeni hasonló elvárásokra.

\section{Az Európa-klauzula az Alaptörvényben}

A 2010-11-es alkotmányozási folyamatban az új alkotmány uniós jogot érintő rendelkezéseiről nem alakult ki érdemi vita. Ez nem meglepő, hiszen az alkotmányozás során a magyar alkotmányos berendezkedést sokkal mélyebben érintő változások körvonalazódtak. A közjogi viták érthetően ezekhez az alapvető alkotmányos kérdésekhez (választójogosultság, alkotmánybíráskodás, bírósági igazgatás, ombudsmani rendszer, egyes alapjogokat érintő változások stb.) kapcsolódtak. A jogtudományban egyébként sem volt általános az az álláspont, miszerint alapvető módosításra szorulna az Alkotmány Európa-klauzulája. Az Alkotmánybíróság esetjogának tudományos értékelésében sem jelent meg az az érv, hogy az esetleges pontatlanságok és mulasztások az Európa-klauzula hibáira lennének visszavezethetők. Egy megfelelően előkészített és részleteiben megvitatott alkotmánykoncepció persze figyelemmel lehetett volna a 2002-es alkotmánymódosítás időszakában közzétett javaslatokra és szakmai kritikákra. ${ }^{43} \mathrm{Az}$ elsietett alkotmányozási eljárás hiányosságai ennek elmaradását megmagyarázzák. ${ }^{44}$

Az Alaptörvény uniós jogot érintő rendelkezései, így az Európa-klauzula szövege első ránézésre alig térnek el az Alkotmány előírásaitól. ${ }^{45} \mathrm{~A} z$ Alaptörvény egyetlen teljesen új előírása az uniós jogszabályok magyarországi alkalmazását lehetővé tévő rendelkezés, amely az Alaptörvény eredeti szövegváltozatában nem is szerepelt. ${ }^{46}$

42 A német Alaptörvény szóban forgó cikkének első mondata: „A Német Szövetségi Köztársaság az egyesült Európa megvalósításához hozzájárul az Európai Unió létrehozásán keresztül, melyet a demokratikus, a jogállami, a társadalmi és a föderatív alapelvek, valamint a szubszidiaritás elve köteleznek és az ezen alaptörvény által biztosított jogvédelemhez lényegében hasonló jogvédelmet biztosít”. A fordítás forrása: Trócsányi László-Badó Attila (szerk.): Nemzeti alkotmányok az Európai Unióban, KJK-KERSZÖV, Budapest, 2005.

43 Az új integrációs klauzula átfogó kritikájához lásd VöRös: Csoportkép Laokoónnal..., i. m., 104-110.

44 Az alkotmányozási folyamat áttekintéséhez lásd BALOGH Éva: Alkotmányozási eljárások Magyarországon (1989-2011), Debreceni Jogi Mühely, 2014/1., http://www.debrecenijogimuhely.hu/archivum/1_2_2014/ alkotmanyozasi_eljarasok_magyarorszagon_1989_2011/(2015.03.01.).

45 Magyarázatul szolgálhat az is, hogy az Alaptörvény előkészítésében nagy szerepet játszó két politikus, Salamon László és Szájer József a 2002-es alkotmánymódosítási eljárásban és konkrétan a 2/A §-ról szóló politikai vitákban is részt vettek (ellenzékben), és az akkori végleges kompromisszumos szöveg kialakításában érvényesíteni tudták álláspontjukat.

46 A bekezdés egy kormánypárti képviselő által jegyzett kapcsolódó módosító javaslattal (T/2627/128.) került az Alaptörvénybe úgy, hogy azt a független képviselőtől származó módosító javaslatot, amelyhez kapcsolódott, már nem tartalmazta. Az eredeti módosító javaslat (T/2627/20.) arra vonatkozott, hogy az uniós alapszerződések jövőbeli módosításait ne az országgyűlési képviselők abszolút kétharmados döntésével, hanem népszavazással kelljen megerősíteni. 
Az Alaptörvény E) cikke, a jelenleg hatályos alkotmányi uniós klauzula így rendelkezik:

(1) Magyarország az európai népek szabadságának, jólétének és biztonságának kiteljesedése érdekében közremüködik az európai egység megteremtésében.

(2) Magyarország az Európai Unióban tagállamként való részvétele érdekében nemzetközi szerződés alapján - az alapító szerződésekből fakadó jogok gyakorlásához és kötelezettségek teljesitéséhez szükséges mértékig - az Alaptörvényböl eredő egyes hatásköreit a többi tagállammal közösen, az Európai Unió intézményei útján gyakorolhatja.

(3) Az Európai Unió joga - a (2) bekezdés keretei között - megállapíthat általánosan kötelező magatartási szabályt.

(4) A (2) bekezdés szerinti nemzetközi szerződés kötelező hatályának elismerésére adott felhatalmazáshoz az országgyülési képviselök kétharmadának szavazata szükséges.

A korábbi Alkotmány 6 . § (4) bekezdésében foglalt államcél változatlan szöveggel az E) cikk (1) bekezdésébe került (az ország hivatalos elnevezésének változása miatt „csak” a Magyar Köztársaság elnevezés módosult Magyarországra). A tartalmilag egyező két rendelkezés rendszertani értelmezése azonban eltérő lehet. Az Alaptörvény az Európa-klauzulával helyezi egy cikkbe az európai egység megteremtésében való közremüködés kötelezettségét, ami azt fejezi ki, hogy az alkotmányozó az európai egységet megvalósító legfontosabb intézménynek az Európai Uniót tartja. Az Alkotmányban ez a célkitüzés a 2/A §-tól elkülönülve, a nemzetközi kapcsolatokról általánosan rendelkező (háború és erőszak elutasítása, együttműködés a világ valamennyi országával) 6 . §-ban szerepelt. Így az EU mellett egyaránt vonatkoztatható volt más európai nemzetközi szervezetekben, például az Európa Tanácsban való együttműködésre is (igaz, a rendelkezés szövegtörténetileg az Európai Unióhoz kötődött). ${ }^{47}$

Az integrációs szerződések alkotmányozó többség általi megerősítését elöíró E) cikk (4) bekezdés tartalmilag szintén egyezik a korábbi alkotmányos rendelkezéssel [2/A § (2) bek.], mindössze a nemzetközi jogi terminológiához jobban illeszkedő precízebb megfogalmazásban (a nemzetközi szerződés "megerösítése és kihirdetése” helyett „kötelező hatályának elismerésére adott felhatalmazás” szerepel).

$\mathrm{Az} \mathrm{E}$ ) cikk (3) bekezdésében foglalt rendelkezés teljesen új, bár indokoltsága megkérdőjelezhető. Az előirás az Alaptörvényben a belső jogszabályokat kimerítően felsoroló T) cikk (2) bekezdését egészíti ki, amely révén alkotmányosan alkalmazhatók egy külső jogalkotó által alkotott, a T) cikkben felsoroltakon kívüli normatív előírások. ${ }^{48} \mathrm{Az}$ uniós jog magyarországi alkalmazhatósága azonban magából az Európa-klauzulából egyébként is levezethető, hiszen annak épp az a funkciója, hogy

47 Csuhány Péter: Az Alaptörvény európai integrációs klauzulája. In Drinóczi Tímea-Jakab András (szerk.): Alkotmányozás Magyarországon 2010-2011 II., Pázmány Press, Budapest-Pécs, 2013, 25-26. Az Alkotmány 6. $§(4)$ bekezdésének fenti értelmezését megerősítette az Alkotmánybíróság Lisszabon-határozata (IV.2.4. pont) is. Az Alaptörvény $E$ ) cikk (1) bekezdését az AB még nem értelmezte.

48 JAKAB András: Fogódzók az új Alaptörvény értelmezéséhez. In Jakab András (szerk.): Az új Alaptörvény keletkezése és gyakorlati következményei, HVG-ORAC, Budapest, 2011, 188. 
alkotmányosan utat nyisson az uniós jog beáramlásának a magyar jogrendszerbe. ${ }^{49}$ Az előírásnak ettől függetlenül lehet fontos szerepe az alkotmánybírósági gyakorlatban, ugyanis a gondolatjelek közé ékelt korlát révén egyértelmű alkotmányos alapot szolgáltathat az Alaptörvénnyel tartalmilag ellentétes (pl. alapjogsértő vagy a jogállamisággal ellentétes), illetve az ultra vires uniós jogi normák magyarországi alkalmazásának kizárásához. ${ }^{50}$

$A z E$ ) cikk (2) bekezdése, maga az Európa-klauzula első ránézésre a korábbival nagyjából azonos szövegezésűnek tűnik, amely továbbra is állandó jogalapot biztosít az uniós jogalkalmazásra Magyarországon. A cikkhez kapcsolódó részletes indokolás a 2/A §-éval egyezően határozza meg az abból fakadó alkotmányos korlátokat is. Figyelmesebb olvasás után azonban a két normaszöveg között érdekes különbség tűnik ki, amely mögött feltételezhető tudatos, messzire vezető alkotmányozói döntés és egyszerü pontosítási szándék is.

A korábbi Európa-klauzula az Európai Unióra átruházott hatáskörök gyakorlásának két módját különböztette meg: fő szabály az alkotmányból eredő hatáskörök „többi tagállammal közös gyakorlása”, amely mellett elképzelhető az „önálló”, az EU intézményei útján megvalósuló hatáskörgyakorlás. Az új Európa-klauzula megfogalmazása szerint azonban csak a többi tagállammal közös hatáskörgyakorlás megengedett, amely ugyan az uniós intézményeken keresztül valósul meg, de kizárja a Magyarország kifejezett részvétele nélküli uniós hatáskörgyakorlást. A látszólag apró megfogalmazásbeli különbség mögött megsejthető az alkotmányozó hatalom elképzelése az európai integráció irányáról (és benne Magyarország szerepéről). ${ }^{51}$ A szöveg kizárja Magyarország részvételét olyan európai integrációs szervezetben, amely a kormányközi együttmüködésen alapuló, a tagállami kormányok részvételével megvalósuló döntéshozatalra épülő struktúrából egy föderálishoz hasonló, a szupranacionális döntéshozatalt általánossá tevő, a tagállami képviselők közvetlen részvétele nélküli hatalomgyakorlásra épülő szervezetté alakul. ${ }^{52} \mathrm{Ez}$ végső esetben kizárja az Európai Unió esetleges föderális átalakítását célzó nemzetközi szerződés Országgyülés általi megerősítésének lehetőségét. A hatályos Európa-klauzulában kifejeződő álláspont egyértelműen szembemegy az európai integráció várható fejlődési irányával, sőt a jelen valóságával is. Nem fejezi ki az uniós kormányzás már ma is létező sokféleségét és összetettségét; nem ismeri el, hogy az uniós döntéshozatal

49 Ezt maga az Alkotmánybíróság is megállapította a 61/B/2005. AB határozatban: „A magyar jogban alkalmazandó közösségi jog éppúgy érvényes az Alkotmány 2/A §-a alapján, mint a magyar jogalkotó által alkotott jog". (III.3. pont.)

50 Ezt megerősíti a rendelkezésre vonatkozó kapcsolódó módosító javaslat indokolása is, amely szerint a rendelkezés azt teszi lehetővé, hogy az uniós jog „azokon a kereteken belül, amelyekben az Európai Unió többi tagállamával való közös hatáskörgyakorlás az Alaptörvény értelmében lehetséges", általánosan kötelező magatartási szabályt megállapítson.

51 Az E) cikkhez kapcsolódó indokolás is a cikkben szereplő módon kizárólag az átadott hatáskörök Magyarország általi gyakorlásáról szól (az uniós intézmények útján).

52 Ezt az értelmezést cáfolja CsuHÁNY: i. m., 11-16. Szerinte a korábbi és az új klauzula lényegi tartalmát tekintve azonos, az új szöveg csak a régit pontosítja, hiszen abban az „önálló közös hatáskörgyakorlásra” való utalás önellentmondást jelentett. Csuhány szerint az új klauzula felhatalmazó ereje a korábbihoz hasonlóan kiterjed a csak közvetett magyar részvétellel működő uniós döntéshozatali mechanizmusok lehetőségére is. Szintén tartalmilag azonosnak tartja a régi és az új klauzulát JAKAB: i. m., 188. 
eredményei a magyar kormány közrehatása nélkül is jelentkezhetnek Magyarországon. ${ }^{53}$

A fenti értelmezést alátámaszthatja az is, hogy a korábbi Alkotmány és az Alaptörvény között alapvető különbség figyelhető meg általában az európai értékekhez, hagyományokhoz való viszony tekintetében. Az Alkotmány Európára való utalást csak az előző pontban felsorolt rendelkezésekben tartalmazott, tehát a választójoggal, az EP-választással, illetve az Országgyülés és a Kormány hatásköreivel kapcsolatban. Ebben a tekintetben az uniós csatlakozást követöen két módosítás történt: 2007-ben a nullum crimen/nulla poena sine lege elveket tartalmazó rendelkezés módosult úgy, hogy az uniós igazságügyi együttmüködésben részt vevő államok joga szerinti elbírálást is említi; illetve 2010-ben, már a későbbi Alaptörvényt megalkotó parlamenti többség (elöjelezve az Alaptörvény hasonló szellemiségét) módosította a szólásszabadságról szóló rendelkezést többek között azzal is, hogy a közszolgálati média feladatának nyilvánította „a nemzeti önazonosság és az európai identitás” ápolását és gazdagítását.

Az Alaptörvény a korábbi szabályozáshoz hasonlóan természetesen megtartotta az uniós tagságból fakadó alkotmányos következményeket a választójogosultság, az EP-választás és a büntetőjogi garanciák tekintetében. Újdonság, hogy az Alaptörvény a korábbi mozaikszerủ alkotmányi szabályozástól eltérően önálló cikkben rendelkezik az Országgyülés és a Kormány európai uniós ügyekben megvalósuló együttműködéséröl, ${ }^{54}$ amelynek logikája (a Lisszaboni Szerződésben foglaltak miatt is) alapvetően eltér a korábbi alkotmányos megoldástól. ${ }^{55}$ Mindezek mellett azonban az Alaptörvény egyéb rendelkezéseiből kiolvasható egy olyan sajátos Európa-felfogás, amely egy erre nyitott Alkotmánybíróság számára akár az Európa-klauzula értelmezését is befolyásolhatja. Az Alaptörvény preambulumában (az ún. Nemzeti hitvallásban) többször tesz utalást Európára, az európai történelemre és az európai közös értékekre:

Büszkék vagyunk arra, hogy Szent István királyunk ezer évvel ezelött szilárd alapokra helyezte a magyar államot, és hazánkat a keresztény Európa részévé tette. [...]

Büszkék vagyunk arra, hogy népünk évszázadokon át harcokban védte Európát, s tehetségével, szorgalmával gyarapitotta közös értékeit. ...

Hisszük, hogy nemzeti kultúránk gazdag hozzájárulás az európai egység sokszínüségéhez.

53 Arató András-Halmai Gábor-Kis János (szerk.): Vélemény Magyarország Alaptörvényéről, Fundamentum, 2011/1., 75; VARJu Márton: Az Alaptörvény és az Európai Unió, Szuverén.hu, 2011. július 9., http://szuveren. hu/jog/az-alaptorveny-es-az-europai-unio. (2015. 03. 01.).

54 Alaptörvény 19. cikk: „Az Országgyűlés tájékoztatást kérhet a Kormánytól az Európai Unió kormányzati részvétellel működő intézményeinek döntéshozatali eljárásában képviselendő kormányálláspontról, és állást foglalhat az eljárásban napirenden szereplő tervezetről. A Kormány az európai uniós döntéshozatal során az Országgyűlés állásfoglalásának alapulvételével jár el”. Az új szabályozás a korábbival ellentétben már nem ír elő kétharmados többséget az együttmüködés részletszabályait meghatározó törvény elfogadásához.

55 Részletesen lásd JuHÁsz-Tóth, Angéla: European Union Law and the Hungarian Parliament: Wasted Opportunities? In Varju-Várnay (eds.): i. m., 84-86. 
Az egyébként szokatlanul terjengős, ideológiai elemekkel teletűzdelt, a keresztény erkölcsi értékek mellett állást foglaló, historizáló bevezető ${ }^{56}$ hazánk Európához tartozását elsősorban történelmi szempontból határozza meg, és a jelenre vonatkozóan a nemzeti értékek és hagyományok védelmét helyezi a középpontba az európai közös értékekkel szemben. Bár a preambulum nem része a normaszövegnek, így nem bír jogilag kötelező erővel, mégis szerepe lehet az Alkotmánybíróság álláspontjának alakításában. Az Alaptörvény R) cikk (3) bekezdése ugyanis - amely már a normaszöveg része - így szól: „Az Alaptörvény rendelkezéseit azok céljával, a benne foglalt Nemzeti hitvallással és történeti alkotmányunk vívmányaival összhangban kell értelmezni" ${ }^{57}$ Így a preambulumban körvonalazódó Európa-szemlélet, amely a nemzeti értékek védelmére helyezi a hangsúlyt, a későbbiekben akár az uniós tagság alkotmányos következményeinek eddigiektől eltérő alkotmánybírósági értelmezésére is vezethet. ${ }^{58} \mathrm{Az}$ európai integrációval szemben védendő nemzeti értékek ideológiájának megjelenéseként értékelhető az Alaptörvény K) cikke is, amely rögzíti, hogy Magyarország hivatalos pénzneme a forint. A rendelkezésnek ugyan még belátható ideig (az euróövezeti csatlakozás erősen bizonytalan időpontjáig) nem lesz gyakorlati jelentősége, a mögötte rejlő ideológia miatt mégis rendkívül barátságtalan üzenetet hordoz az integrációs célkitűzésekkel kapcsolatban. ${ }^{59}$

\section{Az Európa-klauzula alkotmánybírósági értelmezése}

Az Európa-klauzulát az Alkotmánybíróság eddig valamennyi, az uniós és a magyar jog viszonyát érintő határozatában hivatkozta, és több esetben tett a cikkre vonatkozó értelmező megállapításokat is. Ezek a megállapítások azonban meglehetősen felszínesek, magát a klauzula szövegét nem magyarázzák, hanem általában a Magyarország uniós tagságából eredő alkotmányos következményeket határozzák meg (több-kevesebb részletességgel). Az AB a klauzulát mint hazánk uniós tagságának „világos alkotmányi alapját és keretét”60 ismeri el.

56 Bővebben lásd JАKАB: i. m., 180-186; То́тн Gábor Attila: Az új alkotmány preambuluma: előszó vagy seregszemle? Szuverén.hu, 2010. december 20., http://szuveren.hu/jog/az-uj-alkotmany-preambuluma-eloszovagy-seregszemle. (2015. 03. 01.)

57 Az Alkotmánybíróság már több határozatban támaszkodott a Nemzeti hitvallásban foglaltakra, pl. az új egyháztörvény alkotmányossági vizsgálata során [6/2013. (III. 1.) AB határozat], egy közérdekű adatigényléssel kapcsolatos bírósági ítélet felülvizsgálata során [21/2013. (VII. 19.) AB határozat] vagy a szülőtartáshoz kapcsolódó intézményi térítési díjakkal kapcsolatban [27/2013. (X. 9.) AB határozat].

58 A „történeti alkotmány vívmányainak” figyelembevételével körvonalazódó értelmezési lehetőségek még ennél is sokkal bizonytalanabb tartalmúak. Az Európa-klauzula igen fantáziadús értelmezési lehetőségét vázolja a történeti alkotmánnyal való összekapcsolás alapján BrAGYOVA, András: No New(s), Good News? The Fundamental Law and the European Law. In Tóth, Gábor Attila (ed.): Constitution for a Disunited Nation. On Hungary's 2011 Fundamental Law, CEU Press, Budapest-New York, 2012, 349-351. Ezzel szemben lásd JAKAB: i. m., 198-199. Szerinte a történeti alkotmány vívmányainak figyelembevétele az alkotmányértelmezésben nem járhat érdemi jogkövetkezménnyel; ez a fajta értelmezés nem vezethet olyan eredményre, amelyre anélkül nem juthatna az értelmező.

59 Bővebben Bragyova: i. m., 355-356.

60 Lisszabon-döntés, IV.2.2. pont. 
Azt, hogy az $A B$ viszonylag kevés jelentőséget tulajdonít a klauzula tényleges szövegének, jól példázza az Alaptörvény E) cikkéről ez idáig született egyetlen határozat. Ebben a 2012-es döntésben, ${ }^{61}$ amely kifejezetten a cikk értelmezését kérö indítvány alapján született, az AB megállapította, hogy - az előző pontban vázolt állásponttól eltérően - nincs érdemi különbség a korábbi Alkotmány 2/A §-ában foglalt és az Alaptörvény E) cikkében szereplő Európa-klauzula tartalma között.

A döntés alapjául szolgáló indítványt a Kormány terjesztette elö. Ebben azt kérdezte az Alkotmánybíróságtól, hogy az E) cikk (2) bekezdésének hatálya alá tartozik-e, és ennélfogva abszolút kétharmados parlamenti megerősítést igényel-e az Európai Tanács keretében 2012 januárjában elfogadott nemzetközi szerződés „A gazdasági és monetáris unióban megvalósuló stabilitásról, koordinációról és kormányzásról” (mely a közbeszédben Fiskális vagy Stabilitási Paktum néven ismert). ${ }^{62}$ A szerződés értelmében annak részes felei a tagállamok lehetnek, a legtöbb rendelkezését pedig csak az euróövezeti tagokra kell alkalmazni (ha az alkalmazhatóságról egy eurózónán kívüli tagállam előzetesen kifejezetten nem nyilatkozik). Magyarországot tehát sajátos módon érinti a szerződés aláírása: nemzetközi jogi kötelezettséget vállal általa, de annak alkalmazhatósága az euróövezethez való csatlakozás feltételeinek hazánk általi teljesítésétől, majd a Tanács jövőbeli döntésétől függ (amikor az országot euróövezeti tagként elismeri). A szerződés formálisan nem minősül uniós jogforrásnak, de számos tárgykört az alapszerződésekkel párhuzamosan, adott esetben szigorúbban szabályoz, rendelkezéseit az alapszerződésekkel összhangban kell alkalmazni és végrehajtása az uniós jogi és intézményi mechanizmusokon keresztül történik. Az eljárás tehát nem a Fiskális Paktum Alaptörvénnyel való öszszeegyeztethetőségének vizsgálatára irányult, ${ }^{63}$ hanem pusztán annak eldöntésére, hogy az az E) cikk hatálya alá tartozik-e vagy azon kívül eső hagyományos nemzetközi szerződésnek kell tekinteni.

A kérdés megválaszolása szempontjából kulcsfontosságú volt annak eldöntése, hogy a 2/A §-ról korábban adott alkotmánybírósági értelmezés továbbra is irányadó-e. A Lisszaboni Szerződéssel kapcsolatos 2010-es határozat ugyanis már foglalkozott azzal a kérdéssel, hogy milyen szerződések tartoznak az Európa-klauzula hatálya alá. $E$ döntésben az AB kimondta, hogy az abszolút kétharmados parlamenti többség általi megerősítés követelménye nemcsak az uniós tagságot keletkeztető csatlakozási szerződésre vonatkozik, hanem minden olyan szerződésre, amely a jövőben az Alkotmányból eredő további hatáskörök „többi tagállammal közös”, illetve „az Európai Unió intézményei útján” történő gyakorlását teszi szükségessé. Az újabb hatáskör(ök) átruházása újabb nemzetközi szerződés [tipikusan az alapszerződés(ek) módosítása] alapján lehetséges, amelyet ismét abszolút kétharmados parlamenti többségnek kell megerösítenie. Kérdéses volt tehát, hogy a 2/A $\S$ alapján adott értelmezés az E) cikkre is vonatkozik-e.

61 22/2012. (V. 11.) $A B$ határozat, $A B H 2012,10$.

62 http://www.european-council.europa.eu/hu/european-council/pdf/treaty-on-stability-coordination-andgovernance-tscg/ (2015. 03. 01.).

63 A határozat végén $a z A B$ megjegyzi, hogy a szerződést kihirdető törvény később előzetes normakontroll tárgya lehet. 
Az Alkotmánybíróság ezzel kapcsolatban elvi jelentőséggel, általánosságban fogalmazta meg azt a tételt, miszerint az újabb ügyekben felhasználhatja a korábbi Alkotmány alapján hozott határozatokban foglalt értelmezést, ha az Alaptörvény irányadó rendelkezése az Alkotmány rendelkezésével azonos vagy hasonló tartalmú - ez azonban nem jelenti „az előző Alkotmányon alapuló határozatokban kifejtettek vizsgálódás nélküli, mechanikus átvételét, hanem az előző Alkotmány és az Alaptörvény megfelelő szabályainak összevetését és gondos mérlegelést kíván". ${ }^{64}$ A konkrét ügyben az „összevetés és gondos mérlegelés” eredménye az lett, hogy az $A B$ a két vizsgált rendelkezést egymás után idézve megállapította: köztük szövegszerü egyezés van, azok „az eldöntendő értelmezési kérdés szempontjából tartalmilag megegyeznek", így a Lisszabon-döntésben foglalt kritériumok alkalmazhatók. A megállapítás abban a tekintetben aligha bírálható, hogy az abszolút kétharmad követelményére vonatkozó előírások egyeznek a két szövegben (csak terminológiai pontosítás történt). Az e követelménnyel érintett nemzetközi szerződések megkötésére adott alkotmányos felhatalmazás szövege azonban, ahogyan fentebb jeleztem, nem egyezik. Az Alkotmánybíróságtól elvárható lett volna, hogy állást foglaljon e különbség jelentőségéről, még ha végül az idézett végkövetkeztetésre jutott volna is. Ez azonban elmaradt; a testület az érdemi összevetést tulajdonképpen mellőzve arra jutott, hogy a két klauzula azonos alkotmányos követelményeket támaszt az uniós tagsággal kapcsolatban.

A konkrét ügyben tehát a továbbiakban azt a kérdést kellett megválaszolni, hogy a Fiskális Paktum a Lisszabon-döntés értelmében az EU felé új alkotmányos hatáskörök átadását teszi-e szükségessé. Az $A B$ szerint ezt a szerződés alanyai, tárgya és az abból eredő jogok és kötelezettségek alapján lehet megállapítani (mindig konkrét esetre vonatkozóan). Ahhoz, hogy a szerződés az E) cikk hatálya alá tartozzon, szükséges, hogy Magyarország uniós tagállamként legyen részese, abból további alkotmányos hatáskörök átadása következzen - az azonban nem szükséges, hogy ez már a szerződés hatálybalépésekor bekövetkezzen, elég, ha jövőbeli feltételtől függ. A döntés értelmében az E) cikk hatálya alá tartozik az a nemzetközi szerződés is, ami „az alapító szerződések végrehajtására és ennek felügyeletére irányuló új eszközök bevezetésére" irányul, akkor is, ha magát nem minősíti uniós jogforrásnak. Ezen elvi megállapítások alapján az $A B$ konkrétan a Fiskális Paktummal kapcsolatban (megjegyezve, hogy ebben az eljárásban magát a szerződést nem értelmezheti) arra jutott, hogy a fenti jellemzők vonatkoztathatók rá, tehát az E) cikk hatálya alá tartozik. Elsősorban azért, mert korlátozza az Országgyülés hatáskörét a költségvetés meghatározásával kapcsolatban, egyes uniós alapszerződési rendelkezések alkalmazási körét kiterjeszti, és az uniós intézmények számára új hatásköröket hoz létre. ${ }^{65}$

64 A határozat 41. bekezdése.

65 Ugyanakkor megjegyzendő, hogy az E) cikkben foglalt kritérium, miszerint a hatálya alá tartozó nemzetközi szerződés „az alapító szerződésekből fakadó jogok gyakorlásához és kötelezettségek teljesítéséhez szükséges” legyen, a Fiskális Paktum esetében nem teljesül. A hatályos uniós alapszerződésekből ugyanis nem fakadnak olyan jogok és kötelezettségek, amelyek teljesítéséhez szükséges lenne a Paktumban szereplő hatáskörök közös gyakorlása. Ez akkor következett volna be, ha a Paktumban foglaltakat alapszerződés-módosításként fogadták volna el (amire történt is sikertelen kísérlet). Lásd VÁRNAY Ernő: Kommentár a 
Az Alkotmánybíróság szerint tehát a korábbi Alkotmány Európa-klauzulájáról a korábbi határozatokban adott értelmezés az Alaptörvény hatálybalépése után is irányadó - habár ilyen értelmező megállapításokat nem sokat találunk az esetjogban. A Lisszabon-döntés fentebb idézett megállapításai mellett egy 2008-as határozat ${ }^{66}$ érdemel figyelmet, amely a $2 / \mathrm{A} \S$-t beiktató alkotmánymódosító törvény indokolásában foglaltakat magáévá téve megállapította, hogy az Európa-klauzulában adott szerződéskötési felhatalmazásnak két korlátja van: egyrészt a hatáskörök közös gyakorlására csak az uniós alapszerződésekböl fakadó jogok gyakorlásához és kötelezettségek teljesítéséhez szükséges mértékig kerülhet sor, másrészt csak egyes, az Alkotmányból eredő konkrét hatáskörök közös gyakorlására ad lehetöséget. ${ }^{67}$ Azon túl, hogy az AB megismételte az Európa-klauzula parlamenti indokolásában foglalt korlátokat, semmilyen további értelmezést és következtetést nem füzött e megállapításokhoz például azzal kapcsolatban, hogy ki jogosult e korlátok érvényesítésére. ${ }^{68} \mathrm{~A}$ kérdésre a Lisszabon-döntésben találunk választ, bár ott a felhatalmazás alkotmányos korlátait alig részletezi az AB. Eszerint az Európaklauzulában a jövőbeli alkotmányos hatáskörátadásra elöírt „szükséges mértéket” az Alkotmánybíróság „egyedül, más, hazai vagy európai uniós szervtöl függetlenül” vizsgálja. ${ }^{69}$ Ennek a legkedvezöbb esete az AB szerint az, ha az arra jogosultak (itt elsősorban a Kormány jön szóba) a szóban forgó nemzetközi szerződés (tipikusan alapszerződés-módosítás) megerősítése előtt előzetes normakontroll-eljárást kezdeményeznek..$^{70}$

Az Európa-klauzulából következő alkotmányos korlátok tartalmára vonatkozóan a Lisszabon-döntés egy rendkívül fontos megállapítást is tartalmaz, amelyhez azonban sajnos semmilyen további magyarázat és következtetés nem kapcsolódik. A döntés, emlékeztetve a 30/1998. (VI. 25.) AB határozatban megállapított - minden magyarországi jogalkalmazás demokratikus legitimációjának szükségességéről szóló - követelményre, megállapítja: „Az Alkotmány 2/A §-ának érvényesülése azonban nem üresítheti ki az Alkotmány [népszuverenitásról és demokratikus jogállamiságról szóló] 2. § (1) és (2) bekezdésében foglaltakat". Az érvelés ezen a ponton nem világos; mindenesetre a kijelentést értelmezhetjük úgy, hogy az valamiféle kiin-

22/2012. (V. 11.) AB határozathoz (kézirat). Várnay ettöl függetlenül nem vitatja, hogy a Paktum megfelel a Lisszabon-döntésben megfogalmazott kritériumoknak.

66 61/B/2005. AB határozat, $\mathrm{ABH} 2008,1252$.

$67 \mathrm{Az}$ indokolás III.3. pontja.

68 Mi több, e korlátok rögzítésének a konkrét ügy elbírálása szempontjából nem is volt semmilyen jelentősége, ugyanis az ügyben az előzetes döntéshozatali eljárásra vonatkozó magyar jogszabályok közösségi jogellenessége és így a 2/A §-ba ütközése volt az indítvány tárgya, amelyet az AB bevett esetjogára hivatkozva egyszerủen elutasított azzal, hogy nincs hatásköre a magyar jogszabály és a közösségi jog ütközésének vizsgálatára.

69 Lisszabon-döntés, IV.2.2. pont.

70 Az Alaptörvény előkészítése során az AB által megfogalmazott javaslatban szerepelt is, hogy „meghatározott nemzetközi szerződések esetén” kötelező legyen az előzetes normakontroll. (A javaslat nem valósult meg.) [Szerző nélkül] Észrevételek az Alkotmánybíróságra vonatkozó szabályozási elvekről, Alkotmánybírósági Szemle, 2010/2., 101. 
dulópontot nyújt a magyar alkotmány uniós jog által érinthetetlen kemény magjának körülhatárolásához. ${ }^{71}$

Egyebekben az $A B$ az Európa-klauzula alapján inkább az uniós tagsággal kapcsolatos általános megállapításokat tett, tehát az alkotmányos felhatalmazó klauzulából vezette le az uniós jog magyarországi érvényesülésének lehetőségét és következményeit. ${ }^{72}$ Ezek azonban a klauzula konkrét tartalmát (pl. az abban foglalt korlátokat) tulajdonképpen nem érintik. Az AB az Európa-klauzuláról megállapította, hogy az „a Magyar Köztársaságnak az Európai Unióban való tagállami részvétele feltételeit és kereteit, valamint a közösségi jognak a magyar jogforrási rendszerbeli helyét határozza meg"73 (azt, hogy e részvétel keretei pontosan mit jelentenek és pontosan hol van a közösségi jog helye a jogforrási rendszerben, nem tudjuk meg). Kimondta továbbá, hogy a klauzula alapján „a magyar jogban alkalmazandó közösségi jog éppúgy érvényes, mint a magyar jogalkotó által alkotott jog"74 (az, hogy ez hogyan vezethető le a cikkböl és milyen következményekkel jár, szintén nem derül ki). Az Európa-klauzula alkotmánybírósági értelmezése tehát eddig csak a hatálya alá tartozó nemzetközi szerződések sajátosságait érintette részletesen, ezenkívül meglehetősen felszínes maradt. ${ }^{75}$

\section{6. Összegzés}

Az Alkotmánybíróság uniós joggal kapcsolatos esetjogának kiindulópontja az uniós tagság alkotmányos alapja: az Európa-klauzula. Az alkotmányjog-tudományban uralkodó álláspont szerint a klauzula alkotmányba emelése szükségszerü volt, ennek hiányában az uniós csatlakozás és az uniós jog magyarországi alkalmazása nem lett volna alkotmányos. Ezt az érvelést az Alkotmánybíróság 30/1998. (VI. 25.) $A B$ határozata is alátámasztja. Az Alkotmánybíróság a viszonylag szükszavú, kissé homályos tartalmú integrációs klauzulában az uniós tagság alkotmányos keretét igyekszik láttatni, jóllehet az esetjog meglehetősen felszínes ezen alkotmányos keretek meghatározásában.

71 Azt, hogy az AB-n belül felmerült az igény az erre vonatkozó állásfoglalásra (csak a többségi döntésben nem kapott helyet), Trócsányi László párhuzamos indokolása jelzi, aki a német alkotmányjogi dogmatika alapján megkísérelt egy egységes álláspontot meghatározni az uniós tagság által érinthetetlen alkotmányos identitás lényegi elemeiről.

72 Ezért is tekinthető szükségtelennek az Alaptörvény E) cikk (3) bekezdésében foglalt rendelkezés az uniós jog magyarországi alkalmazhatóságáról.

73 1053/E/2005. AB határozat, ABH 2006, 1824, III.1.2. pont.

74 61/B/2005. AB határozat, III.3. pont.

75 Érdekes emlékeztetni az Alkotmánybíróság 2008 és 2014 közötti elnöke, Paczolay Péter egy 2004-es írására, amelyben így nyilatkozott: „A[z Európa-]klauzula egyes elemeinek értelmezése a jövőben valószínűleg még sok izgalmas vitát eredményezhet, különösen invenciózus alkotmánybírósági hozzáállás esetén, legyen szó a nemzetközi szerződés keretfeltételéröl, a közös hatáskörgyakorlás mibenlétéröl, a korlátok megvonásáról, a »szükséges mérték« meghatározásáról. Külön értelmezés tárgya lehet az EK-szerződés 10. cikkében foglalt »hűségklauzulából« eredő kötelességek körének meghatározása". PACzoLAY: i. m., 37-38. A mai napig ilyen „izgalmas viták” legfeljebb az AB zárt ülésein bontakozhattak ki, amelyeknek eredménye egyelöre a határozatokban nem igazán látszik. 
Az Alkotmánybíróság álláspontja jelenleg egyértelműnek látszik arra vonatkozóan, hogy az Alaptörvény Európa-klauzuláját tartalmilag egyezőnek tekinti a korábbi Európa-klauzulával, tehát a 2012 előtt az uniós joggal és az uniós tagság alkotmányos következményeivel kapcsolatban tett megállapításai továbbra is irányadók. A szakirodalomban azonban létezik olyan álláspont is, amely szerint a két normaszöveg alapjaiban különbözik, és teljesen eltérő következtetéseket tesz lehetővé az uniós tagsággal kapcsolatban. Mivel az Alkotmánybíróság várhatóan az Alaptörvény rendszerével szemben messzemenően lojális tagokkal bövül hamarosan, nem tudható, hogyan változik majd a testület álláspontja. Az eddigi gyakorlat irányának változásához mindenesetre megfelelő alapot szolgáltathat az Alaptörvény rendelkezéseiből kiolvasható fokozott szuverenitásféltés és az új alkotmány megváltozott identitása, átalakult viszonyulása az európai alapértékekhez és benne a magyar nemzeti érdekekhez.

\section{Abstract}

The paper examines the Hungarian constitutional framework which determines the relationship between domestic and EU law. The constitutional foundations changed in 2011 when the new constitution, the Fundamental Law was adopted. The former 1989 Constitution contained in Article 2/A the so-called 'European clause' adopted before EU accession, which was referred to as the main constitutional basis of Hungary's EU membership by the Constitutional Court. The new Fundamental Law contains a seemingly similar 'European clause' in Article E. The paper scrutinizes the question whether the former and the new clauses are truly similar and concludes that opposite to the Constitutional Court's point of view the new European clause should be interpreted differently from the former, which might lead to a different, less Europe-friendly approach towards EU membership. 